\title{
VERSITA
}

DOI: $10.2478 /$ abcsj-2013-0017

\section{The Turn to Precarity in Twenty-First Century Fiction}

\author{
JAGO MORRISON \\ Brunel University
}

\begin{abstract}
Recent years have seen several attempts by writers and critics to understand the changed sensibility in post-9/11 fiction through a variety of new -isms. This essay explores this cultural shift in a different way, finding a 'turn to precarity' in twenty-first century fiction characterised by a renewal of interest in the flow and foreclosure of affect, the resurgence of questions about vulnerability and our relationships to the other, and a heightened awareness of the social dynamics of seeing. The essay draws these tendencies together via the work of Judith Butler in Frames of War, in an analysis of Trezza Azzopardi's quasi-biographical study of precarious life, Remember Me.
\end{abstract}

Keywords: 9/11; affect; ageing; Trezza Azzopardi; Judith Butler; fiction; homelessness; precarity; Remember Me; Zadie Smith

Over the last few years there have been several attempts by writers and critics to understand the shift in sensibility that has been so widely detected in twenty-first century fiction. In one characteristic attempt, Irish critic Adam Kelly argues that ours is a distinctively "post-postmodern" period, defined by instability and transition. Citing works by Paul Auster, Jeffrey Eugenides and Philip Roth, he sees the task of contemporary fiction as one of confronting its readers with the ultimate impossibility of interpretation and of witnessing the un-sayability of the Event. For Alison Gibbons, by contrast, the early twenty-first century novel is best considered as "altermodernist," reflecting times that are characterised by unprecedented global dialogue. For the altermodernist writer, in theorist Nicolas Bourriaud's words, "there is no terra incognita any more." 
According to the novelist Zadie Smith, differently again, the state of twenty-first century fiction can best be understood in terms of a generic shift in which metafiction, the flagship mode of postmodernism, has been supplanted by Lyrical Realism. The radical scepticism of Barthes, Pynchon and their contemporaries has, Smith argues, been "relegated to . . literary history" (73) while the literary mainstream has become colonised by "a brief dictated by corporate market research, reasserting the certainties of middlebrow aesthetics" (92). Taking Joseph O'Neill's post9/11 novel Netherland (2008) as symptomatic, Smith is scathing of the contemporary obsession with interiority and the prevalence in recent writing of faux-Flaubertian stylistic indulgence. "Everything must be made literary," she complains. "Nothing escapes. On TV 'dark Baghdad glitter[s] with American bombs.' Even the mini traumas of a middle-class life are given the high lyrical treatment, in what feels, at its best, like a grim satire on the profound fatuity of twenty-first century bourgeois existence" (78-9)

The future of fiction, for Smith, is signposted by the recent emergence of yet another -ism, Necronautism, as exemplified by Tom McCarthy's 2005 novel Remainder. If Lyrical Realists are relentless in their pursuit of the bourgeois soul, the starting points of Necronauts are, instead, that our contemporary being is defined by lack, and that "we know very little, almost nothing" (88). Where Lyrical Realists revel in the "nicely constructed sentence, rich in sound and syntax" (81), Necronauts address their writing to a world in terminal decay. For Necronauts, in a borrowing from Jacques Derrida, "we are all Necronauts, always, already" (89). With its austere aesthetics and absolute refusal of sentimentality, McCarthy's necronautism represents, for Smith, a necessary assault on a literary mainstream mired in complacency. "It clears away a little of the dead wood, offering a glimpse of an alternative road down which the novel might, with difficulty, move forward" (93).

The observations offered by Smith's essay, in particular, on the current state of the fiction industry and those writers who unquestioningly accept its commercial priorities and agendas are, arguably, well placed. How effectively her celebration of Necronautism manages to capture the changed mood in literary fiction over the last decade is much more 
questionable, however. As I will argue here, one of the reasons why her account is not entirely convincing in this regard is that the cultural reorientations to which O'Neill, McCarthy and others are struggling to respond are not ones which can be adequately described in terms of the primarily generic and stylistic opposition she sets out. As both Kelly and Gibbons recognise, in much recent fiction there certainly has been a turn from the carnivalesque aesthetics of high postmodernism, but also a disidentification with some of the sensational philosophic assertions that preoccupied a previous generation. The postmodernist maxim, associated with Francis Fukuyama, that History had Ended since no further challenge to Western liberal capitalism was conceivable, appears just as naïve and premature to writers as it does to intellectuals in post-9/11 times, while the Baudrillard-inspired imaginary of the world-as-Disneyland seems similarly un-adapted for early twenty-first century experience. To try to define the development of fiction over the last decade purely in terms of its supercession or rejection of postmodernism, however, is also to miss the emergence of new concerns and problematics that suggest a more substantive departure from the fiction of the 1980s and 90s. In the work of writers as diverse as Philip Roth, Kazuo Ishiguro, Sarah Waters and J.M Coetzee, I would suggest, one notable aspect of this transition is seen in the resurgence of affect as a central concern in fiction, together with a powerful reassertion of (often anxious) questions about our relationship to, and responsibilities towards, the other. As Adam Kelly says, there is a widespread interest in the idea of historical transitions and aftermaths, but also, in a way that his work does not fully recognise, with ideas of vulnerability and fragility, both personal and social. Finally, in the wake of 9/11 particularly, fictions of the last decade show an increasing interest in the dynamics of seeing, on a social as well as an individual level. This essay attempts to draw these tendencies together in what I am calling the 'turn to precarity' in twenty-first century fiction, drawing on the terms developed in Judith Butler's Frames of War and through the example of one particular novel, Trezza Azzopardi's Remember Me.

The term precarity itself is a relative neologism. Initially, around the turn of the millennium, it began to figure as a term in debates over the changing nature of the labour market in Western economies. Across a 
variety of sectors and over several decades, there had been an accelerating trend towards fluid, flexible modes of employment with progressively lower levels of security and protections. ${ }^{2}$ In this context the notion of the 'precariat' began to be used to describe a broadening class of workers for whom, according to anthropologist Kate Weston, "[j] ob tenure had become more uncertain, sustenance harder to secure, employment more intermittent, health rather difficult to maintain" (431). The notion of precarity evolved quickly, however. By 2007, as a special issue of Feminist Review reported, its analytical scope had expanded to accommodate a much more comprehensive engagement with the idea of social precariousness. According to the issue's authors, over the first few years of the twenty-first century "grassroots activism has transformed [precarity] from being, in the main, an economic category addressing new forms of occupation and labour relations, to a more open instrument of struggle, enabling resistance and the re-imagination of politics, lives and subjectivities, in quite novel ways" (4).

In Judith Butler's work, the concept is extended even further. In Precarious Life and Frames of War in particular, precariousness and interdependency are explored as frameworks for thinking much more broadly about 'human-ness' as a cultural category. From the moment of birth, she suggests, any human life relies for its sustenance and survival on "a shared network of hands" (14). Life is, by its very nature, precarious, and that precariousness necessarily implies a relationship of dependency on the other. The life acknowledged as 'human', for Butler, is a life cared for by others. The life that 'matters,' she argues, is a life whose loss would be something worthy of grieving:

There is no life without the conditions of life that variously sustain life, and those conditions are pervasively social, establishing not the discrete ontology of the person, but rather the interdependency of persons.... The question is not whether a given being is living or not, nor whether the being in question has the status of a 'person'; it is, rather, whether the social conditions of persistence and flourishing are or are not possible. $(19-20)$

In a post-9/11 context, for Butler, part of the usefulness of 'precarity' as a term of analysis is that it moves the ground of debate over ideas of 
violence and loss away from questions of individual moral conscience (as well as from metaphysical conceptions of 'life itself') and towards a consideration of the obligations that arise from the fact that we are "social beings from the start, dependent on what is outside ourselves, on others, on institutions, and on sustained and sustainable environments" (23).

The primary engagements of Frames of War are with US culture in a 'War on Terror' context. Like other thinkers including Naomi Klein, she is interested in the transfiguring effects of violence on the ways we perceive our own precarity and our responsibilities towards others. A specific aspect of this is seeking to understand the cultural effects of the West's collective recognition of vulnerability in the wake of the World Trade Centre attacks, including the fragility of its much-vaunted 'freedoms.' On a more general level, however, Butler is also concerned to explore the changing ways in which, in 9/11's aftermath, ideas of vulnerability and grievability begin to assert themselves in new ways. As Rachel Greenwald Smith argues in an essay on affect and aesthetics in 9/11 fiction, 2001 marked a seismic shift in public perceptions of in/vulnerability in the West. In the US, she argues, this tide of mass affect provided the enabling context for a raft of shifts in US policy, including "the granting of unprecedented executive power to President George W. Bush" (159) and the effective privatisation of swathes of the American military. The smooth accomplishment of previously controversial reconfigurations of state power were, in Smith's analysis, "accomplished largely by seizing on the prevailing sense that the world as we once knew it was destroyed and that anything therefore was possible" (159).

For Al Qaeda, what can be said with certainty on the level of affect is that the lives of those in the planes and in the towers did not matter. Men, women, children, Muslims, Christians, Jews - within the framework of Jihadism the ending of their lives did not merit human recognition. Indeed, according to the official statement on the attacks released by the organisation in April 2002 and repeated by Osama Bin Laden in 2003, "the only motive these young men had was to defend the religion of Allah, their dignity, and their honor [in] a pure act of their will."” In the context of the attacks, it was perfectly permissible for Muslims to kill civilians, the statement argued, because it was "not possible to differentiate [them] 
from the combatants or from the strongholds" represented by the World Trade Centre and the Pentagon (Wiktorowicz \& Kaltner 87). Viewed in relation to this gesture of radical othering, the spectacular violence of America's military response in Afghanistan and Iraq, and the equally intense displays of public grieving for the victims, including their multibillion dollar memorialisation in the form of One World Trade Centre, can all be seen in affective terms as a sustained counter-affirmation of the mattering of those lives.

As Butler shows, however, by the same token that the mattering of some carelessly sacrificed American lives was overwhelmingly affirmed in the nation's response to $9 / 11$, it is also possible to observe the ease with which in the same moment, the lives of many others were able to slip from recognition. Just as Afghan and Iraqi civilians caught at the sharp end of operations Enduring Freedom and Iraqi Freedom failed to reach visibility as grievable, mattering lives to a Western public, so the humanness of opposing combatants held at Guantanamo Bay and Abu Ghraib was systematically elided. As Butler says of the latter:

[W]hen the photos of Abu Ghraib were first released in the US, conservative television pundits argued that it would be un-American to show them. We were not supposed to know that the US had violated internationally recognised human rights. It was un-American to show those photos and un-American to glean information from them as to how the war was being conducted. (40)

What the violence of $9 / 11$ and its aftermath brings to visibility, for Butler, is that 'human-ness' is not an inalienable possession, but something conferred and withheld through the operation of power. Referencing the work of anthropologist Talal Asad, she suggests that our differential emotive and moral reactions to violence must be viewed as "tacitly regulated by certain kinds of interpretive frameworks . . . [W]e feel more horror and revulsion in the face of lives lost under certain conditions than under certain others" (41). The question of which lives come to recognition "as grievable, as worthy of protection, as belonging to subjects with rights that ought to be honored" (41), she argues, is inextricably connected with the frameworks of perception that mobilize and foreclose our affective and ethical response to them. 
In this view, what Butler calls "the politics of moral responsiveness" (41) becomes inseparable from questions of signification, including narrative framing. The work of Frames of War, in this sense, is to call into question those frameworks of representation that facilitate or evoke affective and ethical recognition of some subjects while holding the life-claims of others beneath the threshold of perception. Although (as for the photographer) our ability to focus necessarily requires a restriction of view, and while "there is no seeing without selection" (100), she argues, it is vital that such frameworks of recognition and disavowal do not, themselves, escape scrutiny. For Butler, the task of examining this dynamic of "not seeing in the midst of seeing, this not seeing that is the condition of seeing" (100) represents one of the crucial challenges for cultural analysis bequeathed by $9 / 11$.

In this essay, I have chosen to explore the idea of precarity taken up by Butler through the example of a novel which illustrates its analytic possibilities in some particularly interesting ways. Trezza Azzopardi's Remember Me might seem a strange choice - it would not be classified in any obvious sense as a ' $9 / 11$ novel,' for example. Written in the aftermath of the attacks but set some decades before in Norwich, England, it is both temporally and spatially removed from the events of September 2001, and makes no direct reference to them. Although there is an implicit feminism in her narratives of precarious female lives, Azzopardi is also difficult to place in relation to the field of Contemporary Women's Writing, being most often associated with male figures such as Frank McCourt. In relation to Zadie Smith's 'metafiction versus lyrical realism' opposition, moreover, her work interestingly resists classification, skilfully weaving between modes rather than adhering rigorously to one.

In its exploration of precarious life, like McCarthy's Remainder, Azzopardi's novel is intensely preoccupied with ideas of wreckage, scattered traces and fragments among ruins. Its story space is conjured from rotting and broken structures, whose lost lives are signified by a few talismanic remains among the rubble. Formally too, it is fragmentary, switching between the protagonist's contemporary existence as a destitute, homeless old woman and vignettes of her sometimes happier girlhood and 
young adulthood. At the level of character, Azzopardi is adept at setting up affective identifications for her reader, which the novel then goes on to manipulate and subvert to interesting effect. Like Remainder, her text creates some effects of modernist 'difficulty' and, like many texts of the avant-garde to which Smith does homage, it is also full of metafictional cleverness. At the same time, like O'Neill's Netherland, it is also acutely interested in the aural, evocative and emotive possibilities of language. Though far from bourgeois soul-searching, her protagonist's narrative is full of observational nuance and richness of allusion.

Remember Me focuses on the experience of one precarious subject, a woman called Nora Bridle who lived variously in an abandoned car, in a telephone kiosk and in a covered shopping area in Cardiff throughout the author's growing up. As a girl, Azzopardi would see her among other homeless people in a city arcade, and it was there that her body was found in October 1982, with her dog pining beside it. ${ }^{4}$ Recalling the gathering of 'tramps' in the city centre, Azzopardi said in interview in 2010:

... what struck me about her at the time - and I was five or six - was firstly ... she was the only woman there ... and also because she had ... this amazing hair which was a great big black wig which she wore, I think, right up to the time she died. So for a child, visually she was very striking. She had, sometimes . . . a pram that she had bits in and she always wore interesting clothes from various sources but . . . because she was such a visual character on the streets, people invented stories about her, all kinds of stories about how she ended up there as if that ... was her end point ... to be sitting on a bench with a load of old men drinking cider. ${ }^{5}$

Bridle's strange, ambivalent cultural position - both socially abjected and yet, at the same time, publically owned - provides one of the key problematics that drives Remember Me. In the novel, Azzopardi draws from her history in several specific ways, but also hybridizes her with others, including a woman sleeping rough in Norwich in the 1990s, who lived in a glass security shelter in the middle of a car park. Again, what is striking in the author's description of this woman is the doubleness of her position, on the outer reaches of the social and yet, simultaneously, in the centre of the public gaze. As Azzopardi says: 
. . . again it was like a woman in a glass case. I thought . . . originally I couldn't believe that she lived in this shelter . . . and I though maybe she was an installation, some part of a project. It was so bizarre, but at the time I was quite angry, thinking how could this lovely affluent city allow this poor woman to stand virtually naked in the shelter, in a glass shelter for everyone to see? ${ }^{6}$

If Judith Butler's work draws attention to the dynamics of recognition and visibility, these images evoked by Azzopardi and taken up in Remember $M e$ foreground another layer of complexity in the social dynamics of seeing. What are the workings of a public gaze (not only in war but in the familiar streets of a Western city) that consumes the figure of the abject at the some moment that it negates them?

For Butler, one of the marks of a life recognised as 'human' is the grievability of its loss, and appropriately enough, the initial stimulus for writing Remember Me came to Azzopardi from the display of public grieving that followed Nora's death. Some time after the news became public that her body had been found in the shopping arcade, it emerged that the city of Cardiff had arranged a lavish public funeral for Nora, with feature coverage in the regional newspaper, the South Wales Echo. In interview, the novelist recalls her own affective response: "I was furious." A body whose degradation in life had been complacently regarded by all was now co-opted for a different kind of spectacle, as a corpse to be cleaned, dressed and attended on, with all the signage of a life that had mattered. What seemed to the author to be the flagrant hypocrisy of this display led her to put out her own appeal through the Echo for public recollections of Nora's life, with the idea that they might provide material for a work of fiction based in elements of her biography. The response to her appeal came as a surprise, both in terms of the volume and the variety of responses it provoked. In the imaginations of Cardiff residents, it became clear, Nora had had many different, contradictory lives.

She . . . was a sort of fairytale figure really. She'd been abandoned by a rich Australian fiancée who took all her money; she was the wealthy daughter of a Lord and Lady who didn't want a daughter and only wanted a son so they cast her out into the streets. ... .

In my researches it became evident that she had multiple identities according to the people who talked about her. So she . . had a pram that 
was full of cats; she had a pram that was full of dogs; she had six dogs at one time that all had to be taken away; she rode a horse in the early morning. ... She was a kind of mythical figure as well as being a very real figure. (ibid.)

Like the fairytale figures she had partly become in the collective imagination of Cardiff, the spectacle of Nora's destitution seems somehow to have become integral to the narrative the city told of itself, as well as part of residents' sense of their own local 'colour.' Echoing Butler's work in this sense, Azzopardi's portrait of the precarious subject sees her caught up, precisely, in a dynamic of "not seeing in the midst of seeing" (Butler 100).

In Remember Me, one of the most interesting aspects of Azzopardi's fictive treatment is the way it attempts to reflect this doubleness or ambivalence through the play of affect. Literally scene by scene, as we will see, her writing shapes and reshapes readerly perspective, eliciting and foreclosing our emotional and sympathetic response by turns. In the prologue, she primes us for the ride with a shock, as we are shown an old woman lying petrified in an abandoned building, being robbed of her few possessions by an intruder, who shrieks "like a firework" (2) as she makes her escape. Narrated first person from the old woman's point of view, a space of sympathy is opened for the protagonist, which the author furnishes efficiently with details from her meagre life in the shell of a derelict, former shoe shop, and the tenuous friendships she has established with other homeless people.

As Part One opens Azzopardi takes us far back in time to a picture of the protagonist's beginnings. A young girl, she is to be sent away from home to live with a fearsome grandfather, we discover. Azzopardi places but does not elaborate on the fairytale connotations of the protagonist's plight and, switching to a realist frame, we see the girl, branded "feebleminded" (43), isolated and bullied at school. A sympathetic vignette in the classroom shows her sitting at the back sticking felt animals to a board, while the other children learn the alphabet. Her grandfather is frustrated because she can't tie her shoelaces, can't seem to recall anything - and even as his anger is described, it is difficult for us not to be aware of the sharpness of her narrative voice, as she vividly remembers the instructions 
"right over left, right one under, pull tight, loop on the right. .." (49) that she could not remember. Not for the last time, the reader is offered an experience of parallax: two views of the same scene, which do not quite align. Further displacements of perspective follow. In one, the narrator stands on a bucket to look over a wall and sees a boy balancing on the railway tracks below. Again our view is strangely refracted:

Something was wrong with the picture. Then I saw, exactly, what the boy would have seen. In front of the glasshouse, I spotted her. She was very still, her red hair fuzzed like a halo in the sunshine. She was watching. I felt her fingertips gripping the sooty wall, and her eyes, staring at the bridge. I felt the cold of the bucket seeping up through the soles of her boots. (59-60)

In a later scene, the same girl haunts her with an unsettling presence, always watching her from the other side of the mirror. Is the red haired girl herself? Obviously it is, on one level: much is made of the narrator's own halo of red, "telltale," "pikey" hair. Is this the same (also red-headed) girl who, more than sixty years later, will come sneaking into the squat to steal her things? Although it seems to defy logic, the novel invites us to entertain that possibility. Azzopardi's plot incorporates deliberate elements of uncertainty, and her 'affect plot' does too, as an emotional response to the protagonist is aroused and forestalled.

At home, the girl's mother is shown bedbound and plagued by "ghosts." The girl sees these too: "the black, all around her, a river staining the floor" (44). On the plane of realist representation, however, the mother's confusion, weight loss and pervasive "pear drop" odour suggest a susceptibility of another kind, that of untreated diabetes. How to read the fantastical apparitions, the reader is left uncertain. Taking us back to the present, Azzopardi plays again with reader response by switching modes in a different way, as Winnie rather comically attempts to steal clothes from a washing line and then, in a shocking reverse, is bitten in the face by a dog on the owner's property. We fear the effects may be horrific. Back in the past, her mother becomes entranced with the idea of going to a local dance as the novel replicates, in narrative form, the extended anticipation of her death. 
Up until this point, the mood of Remember Me is predominantly dark. However, Azzopardi now takes her reader to a rather different narrative space, the girl's life with her grandfather. Although strict, he is not a fairytale patriarch as we have been led to expect, and we catch a clear sense of his care for the main character. Her father visits, takes her to the cinema, and does a magic trick. In a flashback, we catch a glimpse of the romance between him and her mother, when she was working as a shoe shop assistant a few years before. As the narrative pace picks up, and the 'affect plot' consolidates into sympathetic desire for better things, Azzopardi's writing conjures an overall sense of gloom lifting. A fleeting accent of foreboding, "I am building a tower . . [1]ater I will bring it down," only slightly darkens the mood. Back in the present, the old woman receives kindness from an assistant in a clothes shop, who cleans the wound on her face and sorts out her hair. In the past, her Grandfather's lodger Mr Stadnik sorts out Lillian's hair too - at her new school she has been bullied by another girl for being a "pikey" redhead. As Mr Stadnik cooks up a chemical mash to bleach it blonde, a magical realist element again suggests itself as he "dances round the room like he's on elastic. He claps his hands with joy. Who is the fairest? he cries" (80).

A timid liaison now begins to build between Lillian and a boy, Joseph Dodd. War is looming, and in a kind of liberation both are evacuated to the country with the other children. Mr Stadnik also hitches a ride in the wagon, braving the spitting and accusations of bystanders. A relationship of trust has built up between him and the girl, and our hopes for her future lift higher as, in the country, Lillian's Aunt Ena and he begin an affair, introducing the girl for the first time to the comfort and security of loving domesticity. Lillian and Joseph begin an affair too, and for a number of pages the dominant affects are hope and desire.

As we enter Part Two, however, Azzopardi engineers another sharp twist of mood. The protagonist is once more in exile, sent away in disgrace when a pregnancy begins to manifest itself. Again the author mixes realist and anti-realist elements, as the girl resolves to drown herself and is saved at the last moment by a clairvoyant. So far, in her father's house, we have been introduced to the protagonist as "Pats", and at her grandfather's, have understood that she's called "Lillian." To Mr Stadnik 
she has been "Princess" and to Joseph Dodd, "Beauty." Now she acquires another identity, Winifred Foy, the visiting "cousin from the country" of Bernard Foy and his "sister" Jean. It emerges that, like her mother, the girl has an affinity with ghosts, and in a development that once again leaves the reader a little unsure how to interpret, she begins a career as a medium. Azzopardi develops the slightly comedic tale of her developing "gift" (is she a charlatan? Bernard Foy certainly seems to be), before inserting a sharp contrast of tone, as the girl is taken to a shoe fitters (we have now seen the shop several times) and is subjected to an un-wanted abortion at the hands of its owner Mr Hewitt. The author now takes us down a rapidly darkening path as the protagonist finds herself homeless again and, after a brief spell in a hostel, returns to an extended encounter with Hewitt that includes her repeated rape. In a pivotal scene, the girl identifies her mother in a photograph with Hewitt: it transpires that her rapist is also her father. The foetus he has aborted was that of his own future grandchild.

As this description indicates, Azzopardi has accelerated the pace of narrative development markedly by the end of Part Two, and in Part Three the succession of events becomes even more frenetic. We learn that, at Hewitt's instigation, Winnie has been incarcerated for twenty-four years in a punitive institution run by nuns: disconcertingly, the author deals with this traumatic episode in just over two pages. Back in the present, the protagonist (now "Winnie") is lured to a meeting with a young woman professional in an upmarket café. The woman confronts her, produces documentation, makes accusations. It begins to become clear that Winnie may have something very serious to answer for in her past. With the increasing pace and sensationalisation of her narrative, the reader has been thrown well off balance by now and, in affective terms, this latest turn works to deepen the sense of confusion. We sense a betrayal looming, as Winnie admits from her own mouth that "I can lie to myself as easily as lying to others. Denial trails me like a dog" (245).

In an unembellished first person account, we are then offered Winnie's testimony to the young woman. On her release from the institution some years before, in the queue at a benefits office, she had gained the trust of a young mother and had used it to steal her baby. 
Winnie describes taking the child back to the shoe shop, and it is at this point that Azzopardi chooses to disclose the act of shocking violence we have been circling from the start:

The skin on a baby's head is so soft, isn't it? Loose fitting, as if the bone underneath is too small for it. It feels like a little skullcap all its own, the skin, moving like velvet under your fingers. Cut the scalp, and it bleeds forever.

I was careful, mind. In the workroom, the whetstone was hard to turn, but I hadn't forgotten. Many long hours I'd spent, watching Hewitt sharpen his blades, listening to the buzz of steel on stone. Hold the edge here, and watch the sparks fly off in a shower, red and white, like the light through the trees when you were made. An edge so fine, Hewitt used to say, travelling the blade along the down on my arm, it could split a hair.

You were very still. I was careful with you, really supremely careful. And I took it all off, every single last hair on your head. . . . It was Telltale, you see. (259)

In terms of the affective plotting of Remember Me, the looked-for effect of this final, violent turn on reader response must be a sharp disidentification with the protagonist and her story. To say the least, a scene of horrific child abuse seems an unusual ending for a novel which seems to present itself as an act of reclamation for the dispossessed. Within a couple of pages, Winnie's narrative has concluded, and the question is left dangling, why Azzopardi would choose to finish her novel in this unsettling and (apparently) perverse way. In terms of the novel's biographical referents, my researches have found no evidence whatsoever linking Nora Bridle to crimes of abduction or acts of scalping, and although the author has declined to allow access to her own archive of correspondence, she has given no indication in response to interview questioning that these narrative elements are drawn from any other account of Nora contributed by the people of Cardiff. In this context, it is difficult to see that the author's insertion of this final, brutal narrative twist can be interpreted in terms of any of the common principles or aspirations ascribed to biographical fiction - faithfulness to an actual biography, the desire to 'do her subject justice,' or the aim of offering her a respectful, sympathetic portrayal. What are the ethics, for Azzopardi, of 
taking a precarious life, even if partly fictionalised and hybridised with the stories of others, and subjecting it to this kind of radical distortion?

As G. Thomas Couser says in Vulnerable Subject: Ethics and Life Writing, on a legal level, the problems with representing a subject who has died are few: "one cannot libel a dead person, and the right to privacy is also held to terminate with death" (6). In this sense, clearly, Azzopardi is free to do what she likes. The ethical implications of representing a vulnerable subject whether dead or alive, however, are surely not so cutand-dried. As in the case of Iris Murdoch, whose husband John Bayley published Elegy for Iris at a time when she was severely affected by dementia but before her death, the problem implicit in attempting to write the life of such a subject is that she is vulnerable to harm through misrepresentation, because her position "deprives her of the capacity to take part in, examine, respond to, or resist that representation" (x). Against that capacity for harm, a conventional argument offered by academic biographer Paul John Eakin is that life writing (whether or not overtly fictionalised) is also a form which can confirm its subject's status as a person, in circumstances when s/he may be unable to tell their own story. As Eakin suggests in The Ethics of Life Writing, "[w]e inhabit systems of social intercourse in which the ability to articulate an identity narrative - whether written, related orally, or simply dropped piece by piece into the social discourse of daily life - confirms the possession of a working identity" (6).

The project of telling Nora's story, as representative of the countless others whose physical and social degradation are so commonly and complacently regarded against backdrops of metropolitan wealth and power, certainly carries ethical force in this latter sense. If Nora's lavish public funeral appeared to the author as an offense to the woman's memory, much of Remember Me's narrative can be read as some form of atonement. At the same time, however, it is difficult not to see a gross act of harming in the novel's final turn to sensationalism, with its presentation of protagonist Winnie as abductor and child abuser.

How to understand this ethical conundrum, which the novel courts so flagrantly? One clue may be provided by Azzopardi's commentary in interview, when she argues that the story of Pats/ Lillian, Princess/ 
Beauty/ Winnie was never intended as an act of simple memorialisation for one person, Nora Bridle. The author's her real quarry in Remember Me is, I would argue, not really the soul or truth of Winnie or of Nora at all, in the sense understood in life writing. What the novel is finally concerned with is less the story of an individual than the nature of the social gaze that, in its doubleness and ambivalence, produces precarity as the dark reflection of its own comfort and security.

In the novel, indeed, it is possible to see how the problematic of 'seeing and not seeing' is explicitly thematized through the figures like the shop assistant Carol, and through the young woman professional, Janice Barrett, whose position researching the history of an ageing vagrant self-consciously reflects the author's own. Our first view of researcher Janice (although we do not immediately recognise it as such) comes, in fact, on the novel's very first page, as she comes creeping in search of the last effects of an old woman whose (she assumes) dead remains lie on the floor of a derelict shop. As she attempts to align the traces of her subject's story, she is unaware that the corpse is watching. Later, frustrated in her search, the young woman attempts to elicit an oral confession from Winnie in the setting of an upscale Italian café, a fortress of class invulnerability. Again, however, our view is doubled through that of Winnie. To the latter, the evidence and documentation flaunted in her face are as good as a gag: "something was trapped in the back of my throat, jamming my words. That was not my life, I wanted to say. Don't think you can own me just because you know my name. A few scraps of paper won't own me" (241). Pressed and cornered, therefore, the account Winnie finally spits out is just "what she wanted to hear; trying not to shout, trying not to roar . . . I am a thief. I don't know any better. I'm not right in the head" (253-4). The Winnie Janice elicits, full of thievery and lies, clutching a baby's cut scalp as an emblem of her jealously and revenge, is of course, nothing but the iconic image of the fairytale crone.

Elsewhere in the novel, however, Azzopardi also represents Winnie's abjection in very different lights. One such scene, probably based on a memory of Nora contributed by the author's sister, is set in a city centre boutique, as Winnie walks in off the street, in need of help: 
She had a shock ... seeing me, and then she did a little bounce on the spot, back down, and turned the music off. . . Mind this till, Debs, she said to the other girl. Debs's face was white coming deep pink up her neck. I'd seen that colouring before: it said something was going on, like a fire alarm or a shoplifter getting caught.

Whatever happened to you! [Carol] said, cheery voice this time. She'd brought back a bowl of pink water and began to wipe the side of my face with it, wrinkling her nose and coughing now and again into her fist. She did my eye first, very carefully, with a nest of cotton-wool balls bunched in her hand. She dropped each one into the waste bin behind her. It was TCP I could smell. (70-1)

Through the doubled view of the salesgirl and the ageing vagrant, Azzopardi shows us the profoundly social nature of her precarity. On the one hand, the scene suggests a fearful exhibition of bodily degradation, and on the other, a glimpse of the fleeting, tenuous relations of care that sustain its life. Indeed, throughout the novel, care's flow and foreclosure is a constantly recurring theme, as spaces of protection and acceptance for the protagonist merge and interchange with experiences of abandonment and exploitation. We see, too, the unstable divisions between caring and violence, at Hewitt's shoe store, where the price of asylum is forced intercourse, and at the Bethel Street asylum, where a punitive and carceral apparatus comes wrapped in the benign cover of 'rehabilitation.' For Winnie, after twenty four years locked up there, "[t]he sisters might as well have killed me as set me free . . . like a sweat of malaria, a night terror from childhood . . . you will never entirely shake it off" (242).

Between the monstrous and the abject, moreover, Azzopardi also makes room for yet another life story, which in a strange redoubling figures middle class Janice rather than homeless Winnie as the truly precarious life. Like the ghosts whose lives inhabit many of Remember $M e$ 's pages, we see here the radical contingency of circumstances that haunt every flickering life story, in its flourishing or erasure.

I could have told her [Janice] I was thinking of a soft spring evening in the church plantation, when she was made, the sun sparkling red through the trees and the scent of the forest beneath me. About Joseph and me planning our escape, in a car, to the end of the world, me and him - and her too, nestled deep inside. . . . How the shoemaker, here, in this very place, took her out of me, piece by piece, with a bone-handled contraption 
used for scoring leather, not knowing, with every cut, that it was his own flesh he tore, his own blood spilled. How for years was afraid to think and unable to speak, because all my thoughts were of her, and all my words about her. She would be $m y$ gift, bringing Joseph back to me - to us - and we could live happily ever after. But I couldn't tell her any of that, because she would think it was a story, and everyone knows that stories aren't real. (253)

If one approach to writing the vulnerable life is to conclude, as Nancy K Miller suggests, that "the truest position is closely related to silence, to self-silencing," this is not the path Azzopardi chooses in Remember Me. Nor does her fictionalised portrait of Nora Bridle and the other precarious subjects she represents offer itself as an attempt to give the truest possible account of a life that would otherwise remain unrepresented. More fruitful is to see her work in relation to that of Judith Butler, for whom the key to understanding precarity is to move our focus beyond the plight of the individual, and onto those frames of perception and representation by whose operation certain lives are apprehended as valuable and grievable in the first place, while others fail to reach the threshold of visibility.

What is interesting about Winnie in this respect, drawn as she is in Azzopardi's evocative and shape-shifting prose, is the way her narrative figures precarity through a succession or multiplicity of life stories that do not settle into easy alignment. She is a child displaced by war, a girl traumatised by violence and rape, an old person without a home, a fairytale pariah. By its continual switching of narrative frames, Remember $M e$ calls its reader's attention to the conditioning of their own affective responses towards the precarious life, and one of the ways it does this is by mobilising a protagonist who, like Nora Bridle herself, exists on real and mythological planes simultaneously.

Read as an exploration of exposure, vulnerability and legacies of violence, Azzopardi's novel sits uneasily alongside works on similar themes from the same period by (for example) Don Delillo, Jonathan Safran Foer, Yasmina Khadra, Jay McInerney and John Updike, with their falling towers and terrorist outrages. ${ }^{7}$ As Winnie says on the novel's opening page, "unless you were looking, I'd be easy to miss" (1). What it does, I would argue however, is to show one possible way in which fiction can rise to the challenge set out by Butler: to begin to understand how our 
responses to exposure, vulnerability and violence are regulated by frames of perception and dynamics of affect that habitually remain unquestioned. In this sense, I would argue that the novel does much, in its modest way, to illuminate the 'turn to precarity' in twenty-first century fiction.

\section{Notes:}

1 "Altermodern: Video Interview with Nicolas Bourriaud," Tate Britain 2008, 28 Aug $2013 \mathrm{http} / / /$ www.tate.org.uk/whats-on/tatebritain/exhibition/altermodern/explain-altermodern/altermodern-video-interview ${ }^{2}$ For an analysis of precarity in the creative industries, see for example Kate Oakley, "In its own image: New Labour and the Cultural Workforce," Cultural Trends 20.3-4 (2011): 281-9.

${ }^{3} \mathrm{Al}$ Qaeda, "A Statement from Qa'idat al-Jihad Regarding the Mandates of the Heroes and the Legality of the Operations in New York and Washington," 24 April 2002, www.alneda.com, quoted by Quintin Wiktorowicz \& John Kaltner, "Killing in the Name of Islam: Al-Qaeda's justification for September 11," Middle East Policy Council Journal 10:2 (Summer 2003), 76-92; 83.

${ }^{4}$ Tony Woolway, "Looking Back," South Wales Echo (1 Nov 2011), 14.

${ }^{5}$ Nick Hubble, Jago Morrison \& Philip Tew, "Interview with Trezza Azzopardi," unpublished, Brunel University, 10 June 2010

6 “Ageing Re-imagined: Trezza Azzopardi's Remember Me" unpublished transcript, Brunel University, 10 June 2010.

${ }^{7}$ e.g. Don Delillo, A Falling Man (2007), Jonathan Safran Foer, Extremely Loud and Incredibly Close (2006), Yasmina Khadra The Attack (2006), Jay McInerney The Good Life (2007), John Updike, Terrorist (2006)

\section{Works Cited}

"Altermodern: Video Interview with Nicholas Bourriaud." Tate Britain. 2008. http://www.tate.org.uk/whats-on/tatebritain/exhibition/altermodern/explain-altermodern/altermodern-videointerview. 28 Aug 2013.

Balyey, John. Elegy for Iris. London: St Martin’s, 2009.

Butler, Judith. Frames of War. New York: Verso, 2009.

---. Precarious Life. London: Verso, 2004.

Couser, G. Thomas. Vulnerable Subjects: Ethics and Life Writing. Ithaca, NY: Cornell U.P., 2004.

Eakin, Paul John, ed. The Ethics of Life Writing. Ithaca, NY: Cornell U.P., 2004.

Fukuyama, Francis. "The End of History." The National Interest (Summer 1989): 3-19. 
Gibbons, Alison. "Altermodernist Fiction." Routledge Companion to Experimental Literature Eds. Bray, J, A Gibbons and B McHale. London: Routledge, 2012. 238-52.

Greenwald Smith, Rachel. "Organic Shrapnel: Affect and Aesthetics in September 11 Fiction." American Literature 83.1 (2011): 153-74.

Italian Core Group. "Introduction.” Feminist Review 87 (2009): 3-4.

Kelly, Adam. "Moments of Decision in Contemporary American Fiction: Roth, Auster, Eugenides." Critique: Studies in Modern Fiction 5 (2010): 313-32.

Klein, Naomi. The Shock Doctrine: The Rise of Disaster Capitalism. New York: Henry Holt, 2007.

Miller, Nancy K. "The Ethics of Betrayal: Diary of a Memoirist." The Ethics of Life Writing. Ed. Eakin, Paul John. Ithaca, NY: Cornell U.P., 2004. 14762.

Oakley, Kate. "New Labour and the Cultural Workforce." Cultural Trends 20.3-4 (2011): 281-9.

Smith, Zadie. "Two Directions for the Novel." Changing My Mind: Essays. London: Hamish Hamilton, 2009. 71-96.

Weston, Kate. "Political Economies of the Precarious." Anthropological Quarterly 85.2 (2012): 429-56.

Wiktorowicz, Quintin, and John Kaltner. "Killing in the Name of Islam: AlQaeda's Justification for September 11.” Middle East Policy Council Journal 10.2 (2003): 76-92.

Woolway, Tony. “Looking Back.” South Wales Echo 1 Nov 2011: 14. 